\title{
AUTONOMIA, NEUTRALNOŚĆ I INDYFERENTNOŚĆ MORALNA PRAWA A JEGO USPOLECZNIENIE*
}

\section{WPROWADZENIE}

Jednym z szerzej dyskutowanych, czy wręcz już klasycznych zagadnień, jakim zajmowały się, zajmują i z dużą dozą prawdopodobieństwa dalej będą zajmować się ogólne nauki o prawie (teoria, filozofia i socjologia prawa), jest relacja między prawem i moralnością. Ten zasadniczy problem badawczy zwykło się wiązać z przeciwstawieniem klasycznie rozumianego pozytywizmu prawniczego i doktryn prawa natury. Obecnie jednak w refleksji naukowej, głównie filozoficznoprawnej, funkcjonuja pojęcia dotyczące tej relacji, które zdają nie wiązać się ściśle z żadną z tych wielkich tradycji. Można do nich zaliczyć autonomię ${ }^{1}$, neutralność i indyferentność moralna prawa. Niniejszy artykuł ma na celu przedstawienie kilku wattpliwości dotyczących autonomii moralnej prawa i neutralności moralnej prawa, które mogą być traktowane jako tożsame koncepcje. Jest to próba zanalizowania ich z socjologicznoprawnej perspektywy, zwłaszcza ze swoistego postulatu, by prawo było jak najbardziej uspołecznione. Z kolei zagadnienie indyferentności moralnej prawa jest przydatne w prowadzonej argumentacji. Krytykuje się tu więc pewna znaną i dość popularną koncepcję z zakresu filozofii prawa/filozofii politycznej - neutralność/autonomię moralną prawa - za pomocą aparatu pojęciowego, jeśli nie dokładnie tych samych dyscyplin naukowych, z których zdaje wywodzić się omawiana koncepcja, to dyscyplin blisko z nimi spokrewnionych (teorii, filozofii i przede wszystkim socjologii prawa). Ze względu na socjologiczną złożoność poruszanych problemów część zagadnień przedstawiono w uproszczony sposób, co podyktowane jest wąsko określonym celem pracy. Nim zostaną omówione krytyczne uwagi dotyczące neutralności/autonomii

*Artykuł jest poprawioną i zaktualizowaną wersja referatu wygłoszonego podczas IV Forum Socjologów Prawa „Sfera publiczna - funkcje, dysfunkcje, normy oficjalne i nieoficjalne”, odbywającego się w ramach XIV Ogólnopolskiego Zjazdu Socjologicznego w Krakowie, 8-11 września $2010 \mathrm{r}$.

${ }^{1}$ Zastrzegając, że problematyka autonomii prawa jest obecna w dyskusji nad współczesnym pozytywizmem prawniczym, ale nadaje się jej inne znaczenie, niż to przytaczane w niniejszym artykule (zob. M. Pichlak, Teza o autonomii prawa we wspótczesnym myśleniu prawniczym, w: M. Araszkiewicz (red.), Z punktu widzenia teorii prawa, „Zeszyty Naukowe Uniwersytetu Jagiellońskiego. Towarzystwo Biblioteki Słuchaczów Prawa. Zeszyty Prawnicze” 2009, z. 16). 
moralnej prawa, potrzebne jest przypomnienie kilku istotnych cech porząków normatywnych będących w centrum zainteresowania tej dyskusji, czyli prawa i moralności, a także przybliżenie znaczenia autonomii, neutralności i indyferentności.

\section{PRAWO I MORALNOŚĆ A USPOLECZNIENIE}

Prawo $^{2}$ wskazuje, co należy czynić, by było to zgodne z wola szeroko pojętego prawodawcy (np. monarchy, wąskiej grupy oligarchów czy członków parlamentu). Normy prawne to zbiór pewnych formalnie obowiązujących wzorów postępowania. Zależne są więc tylko od spełnienia przez legislatora określonej procedury, ta zaś jest wynikiem konwencji takiego, a nie innego formułowania treści tych norm, których poszanowanie jest zabezpieczone możliwością stosowania przez państwo przymusu ${ }^{3}$. To formalne obowiązywanie jest niejako pierwszym etapem w „życiu” prawa, ten rodzaj norm bowiem też może się uspołecznić. O uspołecznieniu można mówić, gdy dana norma ustaliła się i utrwaliła. Ustalenie się normy oznacza, że znacząca część społeczeństwa posiada w miarę jednakową wiedze o jej treści, a ponadto żywi przekonanie o jej obowiązywaniu, że jest właściwym sposobem postępowania. Utrwalenie się normy jest zaś stanem, gdy równie znacząca część społeczeństwa charakteryzuje się gotowością do postępowania zgodnego z tą normą i podobna większość faktycznie jej przestrzega w codziennym życiu ${ }^{4}$. Można zatem w uproszczeniu powiedzieć, że norma uspołeczniona to taka, która rzeczywiście, bez konieczności przymusowego egzekwowania, ,zewnętrznego”, instytucjonalnego wsparcia, wpływa na postępowanie. Jest faktycznym regulatorem działań ludzi; tym, co jest, a nie „tylko” tym, co być powinno. Co jednak istotnie odróżnia normy prawne od pozaprawnych, to fakt, że często mimo braku uspołecznienia, specjalnie do tego powołane instytucje będą wciąż takie normy egzekwowały i sankcjonowały wykryte naruszenia. Jednakże stan powszechnego braku uspołecznienia prawa jest dla ustawodawcy wysoce niepożądany. Egzekwowanie takiego prawa wymaga bowiem dodatkowych nakładów instytucjonalnych, a co za tym idzie - także ekonomicznych. Powoduje również spadek ogólnie pojmowanego prestiżu prawa, co może jeszcze silniej wpływać negatywnie na przestrzeganie jego norm. $\mathrm{Z}$ tych względów istotne jest podejmowanie dodatkowych zabiegów ze strony legislatora, by wydawane prawo uspołeczniło się. Prawodawca nie może ograniczyć się tylko do wydania normy, ale winien również odpowiednio rozpowszechniać jej treść i pogłębiać legitymizację.

\footnotetext{
${ }^{2}$ Opis prawa w dużej mierze opiera się na rozważaniach K. Pałeckiego (Prawoznawstwo. Zarys wyktadu. Prawo w porzadku spotecznym, Warszawa 2003, s. 117-119).

${ }_{3}^{3}$ Posługiwanie się tak waskim rozumieniem prawa jest podyktowane celem niniejszego artykułu, czyli analizą koncepcji neutralności/autonomii moralnej prawa. Zakłada ona taka - w istocie klasycznie pozytywistyczną - wizję prawa (zob. M. Błachut, Postulat neutralności moralnej prawa a konstytucyjna zasada równości, Wrocław 2005, s. 14).

${ }^{4} \mathrm{O}$ uspołecznieniu, zob. K. Pałecki, op. cit., s. 53-73.
} 
Z kolei moralność ${ }^{5}$ określa, co czynić, by postępować słusznie, prawdziwie, dobrze, czy uczciwie. Trudności w opisywaniu jej wiążą się nie tylko z tym, że treść norm moralnych jest często w dużej mierze zbieżna z treścią określonych norm religijnych i prawnych, ale również z dwojakim rozumieniem moralności ${ }^{6}$ Tak zwana moralność opisowa stanowi zbiór faktycznie funkcjonujacych, przeżywanych norm. Są to zatem pewne prawidła, reguły rządzące danym społeczeństwem, a nie tylko postulaty czy zalecenia. Niezależnie od ewentualnego wyróżniania opisowych moralności partykularnych (obowiąujących i wykształconych przez stosunkowo homogeniczne grupy) i opisowej moralności uniwersalnej (obejmującej swoim oddziaływaniem cały konkretny porządek społeczny), to właśnie wspólne dla obu tych rodzajów uznanie danych reguł za „swoje” odróżnia kategorię moralności deskryptywnej od normatywnej. Moralność normatywna stanowi bowiem ,jedynie” autorski projekt, w którym ktoś wskazuje, co w jego mniemaniu jest najlepsze czy słuszne, ale co niekoniecznie musi być społecznie akceptowane. Dopiero gdy te postulaty zdobędą uznanie, zaczną być przeżywane i stosowane przez innych ludzi, staną się moralnością opisową ${ }^{7}$. Obowiązywanie moralności bierze się bowiem z przekonania o słuszności określonych prawideł postępowania, które traktowane są przez członków danego społeczeństwa jako „swoje” reguły. Można je więc traktować jako normy uspołecznione. Należy jednak nadmienić, że nawet w stosunkowo jednolitych zbiorowościach funkcjonuje wiele moralności (deskryptywnych uspołecznionych i normatywnych - nieuspołecznionych, zarówno grupowych, jak i jednostkowych, indywidualnych), które moga pozostawać ze sobą w konflikcie.

\section{AUTONOMIA, NEUTRALNOŚĆ I INDYFERENTNOŚĆ MORALNA PRAWA}

Przechodząc do omówienia pojęć autonomii, neutralności i indyferentności, najpierw należy odnieść się do najbardziej ogólnego - autonomii. Jest ona tłumaczona jako względna niezależność, odrębność prawa od wszystkiego co „pozaprawne”. Ze względu na to, co dokładnie będzie się rozumieć przez te pozaprawne czynniki, można mieć do czynienia z różnymi koncepcjami samej autonomii prawa9 ${ }^{9}$ Oprócz niezależności prawa od polityki, według której decyzje polityczne mają być tylko realizacją norm prawnych, wyróżnia się także autonomię moralną, dotyczącą możliwości działania prawa niezależnie

\footnotetext{
${ }^{5}$ Opis moralności, podobnie jak prawa, opiera się w dużej mierze na rozważaniach K. Pałeckiego, op. cit., s. 100-103, 107 i 111.

${ }^{6}$ Ibidem, s. 101.

7 Odwołując się do rozważań M. Ossowskiej (np. Podstawy nauki o moralności, Warszawa 1947), moralność deskryptywną można utożsamiać po prostu z moralnościa, natomiast moralność normatywną z etyką (określoną doktryną etyczna).

${ }^{8}$ W. Gromski, Autonomia i instrumentalny charakter prawa, Wrocław 2000, s. 13.

${ }_{9}$ M. Wierzbicki, Autonomia prawa, w: J. Zajadło (red.), Leksykon współczesnej teorii i filozofii prawa. 100 podstawowych pojęć, Warszawa 2007, s. 18.
} 
od „wsparcia ze strony moralności” ${ }^{10}$. Ponadto tezę o autonomii prawa interpretuje się na cztery różne sposoby ${ }^{11}$. Interpretacja ontologiczna skupia się na próbie odpowiedzi na pytanie, czy prawo jest samodzielnym, samoistnym bytem kulturowym. Ujęcie poznawcze autonomii dotyczy kilku zagadnień. W zależności od rozwiązania problemu relacji podmiot-przedmiot poznania prawo jawi się albo jako „zewnętrzny w stosunku do badacza” obiekt, albo jako byt kształtowany przez poznającego, niemajacy zatem „obiektywnej”, niezależnej od obserwatora charakterystyki. Poza tym poznawcza interpretacja odnosi się do zagadnienia nauki prawa jako autonomicznej, „zrywajacej" z integracją zewnętrzną z szeroko pojmowanymi naukami pozaprawnymi oraz swoistości rozumowań prawniczych. Trzeci sens autonomii, aksjologiczny skoncentrowany jest na kwestii, czy prawo stanowi wartość samą w sobie, oraz na zagadnieniu „wewnętrznej moralności prawa”. Ostatnia interpretacja - funkcjonalna dotyczy problemu określenia stopnia, w jakim prawo może samodzielnie, bez „zewnętrznego wsparcia” wpływać na postępowania poszczególnych jednostek, a przez to kształtować ogół życia społecznego.

Można zaryzykować twierdzenie, że na autonomię moralną prawa najwłaściwiej jest spojrzeć przez pryzmat interpretacji ontologicznej i funkcjonalnej. Wciąż jednak pozostaje bliżej określić, na czym owa niezależność od „wsparcia ze strony moralności" ma polegać. Najprostszą odpowiedzią byłoby daleko posunięte abstrahowanie przez prawo od moralności. Jest ona jednak w zdecydowanej mierze kontrfaktyczna. Bardzo wiele norm prawnych stanowi przecież „powielenie”, prawne „usankcjonowanie” określonych norm moralnych. Dlatego zasadne wydaje się sprowadzenie przedstawionego powyżej bardzo ogólnego rozumienia autonomii moralnej prawa do neutralności moralnej prawa $^{12}$.

Ta koncepcja, wiązana z szeroko pojęta myśla liberalna, ma stanowić próbę rozwiązania istotnego problemu, że obserwowanemu we współczesnych państwach pluralizmowi indywidualnych sposobów, planów na życie czy jednostkowych moralności towarzyszy jeden porządek prawny. Wychodząc z tej obserwacji, neutralność moralna prawa rozumie się jako „zakaz preferowania pewnych koncepcji moralności prywatnej" ${ }^{13}$. Temu ogólnemu sformułowaniu można przypisać cztery znaczenia ${ }^{14}$. Neutralność szans sprowadza się do

${ }^{10}$ W. Gromski, op. cit., s. 30; M. Wierzbicki, op. cit., s. 19; M. Pichlak, op. cit., s. 29

11 W. Gromski, op. cit., s. 22-26; M. Wierzbicki, op. cit., s. 20-21; M. Pichlak, op. cit., s. 27-28.

${ }^{12} \mathrm{~Np}$. W. Gromski (op. cit., s. 13-14) w swoich rozważaniach dotyczących szeroko pojmowanej odrębności prawa od wszystkiego co pozaprawne jako pojęcia odnoszące się do tej problematyki wymienia legal closure oraz autopoiesis prawa, jednocześnie odrzucając możliwość zamiennego używania tych pojęć z autonomią prawa. Nie wskazuje jednak żadnych przeciwwskazań do synonimicznego używania pojęcia neutralności moralnej prawa. Z kolei M. Wierzbicki (op. cit., s. 19) wprost tłumaczy autonomię moralną prawa (niezależność prawa od moralności) jako zasadę, że „W trakcie podejmowania decyzji w zakresie tworzenia i stosowania prawa należy odrzucić motywacje oparte na założeniu, że pewne sposoby życia są lepsze od innych”. Takie ujęcie jest bardzo zbliżone do spotykanych w literaturze sposobów definiowania neutralności moralnej prawa.

${ }^{13}$ M. Błachut, op. cit., s. 7.

${ }^{14}$ Ibidem, s. 23. Inaczej W. Ciszewski, W strone „miękkiej” neutralności światopogladowej państwa, „Państwo i Prawo” 2014, z. 6, s. 8. 
postulatu, by prawo umożliwiało byt wszystkim sposobom, pomysłom na życie. Kolejne znaczenie - neutralność rezultatów ma polegać na zakazie uprzywilejowanego traktowania przez prawo jednego stylu życia, kosztem innych. Z kolei przez neutralność proceduralna postuluje się, by podejmowanych decyzji prawnych nie można było uzasadniać tym, że określony sposób życia jest lepszy bądź gorszy od innych. Ostatnią neutralność celu można traktować jako zasadę, by prawo nie faworyzowało ani nie wspierało danych sposobów dobrego życia w większym stopniu niż innych koncepcji.

Najpowszechniejszym ujęciem jest trzeci wariant - neutralność proceduralna ${ }^{15}$. Jest ona rodzajem postulowanej, wymaganej postawy, jaka winien charakteryzować się legislator. Zakazuje się tworzenia prawa, opierając się na przekonaniu, motywie, że pewne moralności, pomysły na życie sa cenniejsze od innych ${ }^{16}$. Decyzje ograniczające wolność mają być tak uzasadniane, by nie można było ich posądzić o to, że są wyrazem przedkładania czy deprecjonowania określonej „formy ludzkiej autokreacji” ${ }^{17}$. Jeśli odnieść te uwagi do opisanego zagadnienia autonomii moralnej prawa, „wsparcie ze strony moralności” można więc rozumieć jako przekonanie prawodawcy o większej (mniejszej) wartości określonego postępowania, które oceniane jest przez niego jako dobre, sprawiedliwe i słuszne lub jako całkowite zaprzeczenie tych ideałów oraz adekwatnie do tych ocen prawnie uregulowane.

Podkreśla się, że wyrugowanie z procesu prawodawczego motywacji opartych na ocenach w kategoriach dobrej lub złej koncepcji życia bądź sposobu postępowania wcale nie musi prowadzić do neutralnych skutków ${ }^{18}$. Te ostatnie można rozumieć na trzy sposoby. Moga to być konkretne przepis czy cały porządek prawny albo umożliwiający istnienie wszystkich sposobów życia (odnosząc się do neutralności szans), albo niepreferujący jednej moralności i w związku z tym nieszkodzący innym moralnościom (odnosząc się do neutralności rezultatów), albo niewspierający określonego sposobu życia w większym stopniu niż pozostałe (odnosząc się do neutralności celu). Należy więc podkreślić, że neutralność/autonomia moralna prawa (w jej najpowszechniejszym,

15 M. Błachut, op. cit., s. 24, 162 i 172. Por. np. W. Sadurski, Neutralność moralna prawa (Przyczynek do teorii prawa liberalnego), „Państwo i Prawo” 1990, z. 7, s. 32 i 34; T. Pietrzykowski, Etyczne problemy prawa. Zarys wyktadu, Katowice 2005, s. 132; idem, Etyczne problemy prawa, Warszawa 2011, s. 91-92; T. Pietrzykowski, Z. Tobor, Postulat neutralności w porzqdku prawnym, w: O. Bogucki, S. Czepita (red.), System prawny a porzadek prawny, Szczecin 2008, s. 180; D. Bunikowski, Podstawowe kontrowersje dotyczace ingerencji prawa w sfere moralności, Toruń 2010, s. 133-134; W. Brzozowski, Bezstronność światopogladowa władz publicznych w Konstytucji RP, Warszawa 2011, s. 226 i 236; W. Ciszewski, op. cit., s. 16.

${ }^{16} \mathrm{~Np}$. W. Sadurski (op. cit., s. 32) pisze, że „prawodawca w stosowaniu przymusu nie może kierować się niechęcią wobec systemu moralnego, wyrażonego w danym akcie czy zachowaniu zakazanym przez prawo. Prawodawca nie może kierować się przekonaniem, że pewne koncepcje moralne powinny być preferowane względem innych, że on sam ma jakiśs uprzywilejowany wgląd w rozumowanie moralne, które pozwala mu kwalifikować pewne moralności jako bardziej pożądane niż inne".

17 M. Błachut, op. cit., s. 25.

18 Ibidem, s. 24. Jak słusznie zaznaczają T. Pietrzykowski i Z. Tobor (op. cit., s. 178), „o zachowaniu postawy neutralności decydują bowiem racje danego postępowania, a nie jego skutki”. 
proceduralnym ujęciu) odnosi się tylko do oceny motywów prawodawcy. To, czy skutki jego działalności będą rzeczywiście neutralne, w powyżej opisanych znaczeniach, jest kwestią oceny samego prawa. To ostatnie zagadnienie może być analizowane przez pojęcie indyferentności moralnej prawa.

Przepis moralnie obojętny normuje postępowania, które nie są równocześnie normowane przez moralność ${ }^{19}$. Można ten problem także ująć $\mathrm{w}$ formie pytania: Czy prawo zawiera treści w ogóle niekorespondujące z określonymi normami moralnymi? ${ }^{20}$ Próba odpowiedzi na nie nigdy nie będzie jednoznaczna i będzie zależała od przyjętego „punktu wyjścia”, stanowiska, z którego dopiero będzie się formułować opinie o indyferentności lub jej braku ${ }^{21}$. Z szeregu proponowanych ujęć jedno z wymienionych przez Józefa Nowackiego zasługuje na szczególną uwagę. Obojętność moralna określonych przepisów -jego zdaniem tak naprawdę zależy od przyjętej perspektywy ${ }^{22}$. Jeśli na pewne regulacje spojrzy się jako na jeden z elementów większej całości, struktury, ogniwa łańcucha, to łatwo odnaleźć ich związek z jakaś moralnie nieobojętną zasadą prawa, a co za tym idzie - przepisy te okażą się w pewnym stopniu „nasycone” treściami moralnymi ${ }^{23}$. Jeśli jednak nie przyjmie się takiej szerszej optyki i skupi się tylko na postanowieniach jednego, konkretnego przepisu, to jego ocena może się zmienić diametralnie i może być on uznany za obojętny moralnie ${ }^{24}$.

Nowacki koncentruje się na przepisach quasi-indyferentnych, czyli prima facie nieposiadajacych odpowiedników w normach moralnych, ale wykazujacych $\mathrm{w}$ bliższej lub $\mathrm{w}$ dalszej perspektywie związek z przepisami prawnymi, które wyraźnie odwołuja się do moralności ${ }^{25}$. Choć tego nie przyjmuje, wydaje się jednak, że przy odpowiednio szerokiej perspektywie można odnaleźć związek (rzekomo) całkowicie indyferentnych przepisów ${ }^{26} \mathrm{z}$ jakąś normą moralną. Takie podejście, obecne w literaturze ${ }^{27}$, sprawia, że podział na przepisy indyferentne, quasi-indyferentne oraz mające wprost uzasadnienie w moralności wydaje się tracić na znaczeniu. Przyjęcie poglądu, że problem określenia „moralnego nasycenia” norm prawnych i jego stopnia jest zależny od przyjętej perspektywy, jest natomiast przydatny do krytycznej analizy koncepcji neutralności/autonomii moralnej prawa.

19 J. Nowacki, Problem moralnej indyferentności przepisów prawa pozytywnego, w: idem, Studia z teorii prawa, Kraków 2003, s. 183.

${ }^{20}$ Podobne pytanie, ale odnosząc je ściśle do prawa karnego, zadaje A. Wąsek (Prawo karne - minimum moralności?, „Annales Universitatis Mariae Curie-Skłodowska” 1984, t. 31, 3, Sectio G, s. 47).

21 J. Nowacki, op. cit., s. 212-213.

22 Ibidem, s. 193-194.

${ }^{23}$ Ibidem, s. 193.

24 Ibidem.

25 Ibidem, s. 191.

${ }^{26}$ Ibidem, s. 190.

${ }_{27} \mathrm{~Np}$. pogląd M. Ossowskiej twierdzącej, że moralność jest nawet w tych regulacjach, które wydają się od niej całkowicie niezależne, oraz opinia G. Riperta (za: A. Krukowski, Polityka kryminalna - Prawo karne - Moralność: zwiazki i antynomie, w: J. Kurczewski (red.), Prawo w spoteczeństwie, Warszawa 1975, s. 436). Podobnie wypowiada się J. Stelmach (Próba systematyzacji treści moralnych wystepujacych w polskim Kodeksie Karnym z 1969 roku, „Zeszyty Naukowe Uniwersytetu Jagiellońskiego. Prace z Nauk Politycznych” 1979, nr 12, s. 91). 


\section{NEUTRALNOŚĆ/AUTONOMIA MORALNA PRAWA Z SOCJOLOGICZNOPRAWNEJ PERSPEKTYWY}

Pierwsze pytanie, jakie należy postawić, to: O czyją i jaką moralność w omawianym zakresie chodzi? W dyskusji nad wspomnianymi zagadnieniami szczególną uwagę poświęcono perspektywie ustawodawcy, a nie adresatów - osób, które mają być posłuszne prawu. Wciąż jednak wiele wątpliwości może budzić charakter ocen, źródło motywów faworyzowania lub dezaprobowania jakiejśs koncepcji życia, które mają być wyrugowane lub znacznie ograniczone w procesie prawodawczym. W świetle wcześniejszych uwag dotyczących samej moralności wydaje się, że istnieja cztery warianty. Może to być moralność deskryptywna legislatora, moralność deskryptywna znaczącej części adresatów, moralność normatywna legislatora bądź jakaś z moralności normatywnych występujących wśród adresatów prawa. Na podstawie literatury dotyczącej neutralności/ autonomii moralnej prawa trudno jednoznacznie rozstrzygnąć ten problem ${ }^{28}$.

Sam prawodawca majacy wystrzegać się w podejmowanych przez siebie decyzjach pewnej ogólnie określonej klasy motywów, których podstawy, źródła moga być, jak pokazano, bardzo różnorodne, nie jest abstrakcyjnym bytem. We współczesnych realiach jest to najczęściej grupa konkretnych ludzi z krwi i kości wchodzących w skład danego ciała kolektywnego ${ }^{29}$. Zatem zdaje się, że uzasadnione jest pytanie: Czy mogą oni w swojej pracy odciąć się od przekonań moralnych (zarówno tych rzeczywiście przeżywanych, jak i „tylko” postulowanych)? Chyba nie będzie przesadą powiedzieć, że faktyczna możliwość wyrugowania własnych sądów moralnych czy niezważania na nie w procesie prawodawczym jest bardzo problematyczna. Nawet jeśli hipotetycznie uda się tego dokonać, to - jak powyżej zauważono - nie gwarantuje to neutralnego prawa. Istnieją dwa główne, powiązane ze sobą powody tej nieprzekładalności motywów na skutki.

Przede wszystkim trzeba zauważyć, że motywy moralne sąjednymi z całego spektrum możliwych przesłanek podjęcia konkretnej decyzji prawodawczej. Powstanie danej regulacji może być i najczęściej jest wynikiem wielu przekonań, np. dotyczących pragmatyki czy przewidywanej „ekonomiczności” danego prawa. Ta uwaga - w kontekście wcześniej wspomnianego nakazu takiego uzasadniania decyzji prawodawczych, by nie mogły one być traktowane jako prze-

\footnotetext{
${ }^{28}$ Np. W. Sadurski (op. cit., s. 32) mówi o zakazie kierowania się „niechęcią wobec systemu moralnego" i „przekonaniem, że pewne koncepcje moralne powinny być preferowane względem innych”. M. Błachut (op. cit., s. 25) mówi o wyeliminowaniu motywacji, że „pewne formy ludzkiej autokreacji sa bardziej wartościowe od innych". Z kolei T. Pietrzykowski (Etyczne problemy..., s. 132) omawiany postulat rozumie jako przeciwwskazanie do implementowania „do postanowień prawa przekonań dyktowanych żadną konkretną doktryną moralna”, podkreślając, że dotyczy on „motywów i postawy prawodawcy” (por. idem, Etyczne problemy..., s. 91-92). Natomiast W. Ciszewski (op. cit., s. 15) uważa, że „lepszą propozycję określenia punktu odniesienia [komentowanej - M.D.] zasady stanowią tzw. kontrowersyjne koncepcje dobrego życia o charakterze religijnym, światopoglądowym i filozoficznym".

${ }^{29}$ Tak pojmowana realność prawodawcy jest bardzo często ignorowana w dyskusji na temat neutralności/autonomii moralnej prawa. Zob. np. W. Sadurski, op. cit., s. 36 i 38; M. Błachut, op. cit., s. 135-136; W. Brzozowski, op. cit., s. 142.
} 
jaw preferencji bądź niechęci wobec jakiejś moralności - zdaje się usprawiedliwiać tezę, że neutralność/autonomia moralna prawa może wręcz wymuszać na prawodawcy manipulację, ukrywanie prawdziwych motywów pod pozorem pojęć np. użyteczności czy bezpieczeństwa. Oczywiście, one też są wartościami, które mogą być traktowane jako moralne. Należy jednak zgodzić się z Wiesławem Langiem ${ }^{30}$, który zauważa, iż obok (1) wartości zawsze, bezsprzecznie kwalifikowanych jako moralne, istnieją (2) dobra powszechnie niezaliczane do moralnych oraz (3) takie, których przypisanie do tej kategorii jest przedmiotem kontrowersji i sporów. Uzasadnianie konkretnej regulacji przez motywy zaliczane do drugiego lub trzeciego rodzaju, w sytuacji gdy jednak na jej ostateczny kształt zasadniczy wpływ miały jedynie przekonania „ewidentnie” moralne, można traktować jako swojego rodzaju normę nieoficjalna stosowana przez prawodawcę $\mathrm{w}$ procesie tworzenia prawa. Można zaryzykować twierdzenie, że w znaczącej mierze sprowadzi to uzasadnianie norm prawnych do mniej lub bardziej wyszukanych zabiegów argumentacyjnych, które wcale nie muszą dokładnie odpowiadać rzeczywistym powodom, motywom, które doprowadziły do ich uchwalenia ${ }^{31}$. Ze względu na to, że prawo nieneutralne wciąż może być wydane i obowiązywać, omawiany postulat neutralności/autonomii moralnej prawa dla adresatów konkretnych regulacji może jawić się jako wysoce fasadowy i apragmatyczny, a próby jego realizacji mogą prowadzić do zjawiska neutralizacji wartości w prawie ${ }^{32}$.

${ }^{30}$ W. Lang, Prawo i moralność, Warszawa 1989, s. 32.

${ }^{31}$ Wydaje się, że w polskich realiach przykładów takich zabiegów można doszukiwać się w legislacji dotyczącej problemów bioetycznych. Np. Komitet Inicjatywy Ustawodawczej „Contra In Vitro" w przygotowanym przez siebie projekcie ustawy o zmianie ustawy - Kodeks karny z dnia 15 czerwca 2009 r. (druk nr 2249 z VI kadencji Sejmu RP - http://orka.sejm.gov.pl/Druki6ka. nsf/0/0509A31DD07E8E9BC125761E0037190C/\$file/2249.pdf [dostęp 5.09.2014]), proponował wprowadzenie do rozdziału XIX k.k. (Przestępstwa przeciwko życiu i zdrowiu) nowego przepisu art. 160a k.k., przewidującego m.in. kryminalizację zabiegów in vitro. W nadzwyczaj zdawkowym uzasadnieniu tego projektu jego autorzy bardzo często powołują się na kategorie godności ludzkiej i praw człowieka, choć można podejrzewać, że tak naprawdę przyświecały im nie te „świeckie” koncepcje, lecz religia chrześcijańska (najpewniej katolicyzm). Co warte podkreślenia, to podejrzenie nie jest spowodowane i uprawdopodobnione przez konkretne wypowiedzi w uzasadnieniu, lecz przez logo wspomnianego Komitetu, znajdujące się w komplecie dokumentów do komentowanego druku sejmowego. Jest na nim bowiem umieszczony symbol ryby (ichthys), a więc jeden z kanonicznych elementów symboliki chrześcijańskiej (o tym projekcie zob. także M. Dudek, Instrumentalization of the Law and Neutralization of Values in Law. Some Reflections after Reading the Draft Amendments of the Special Part of Polish Penal Code of the Sixth Term of Office of the Polish Sejm (2007-2011), w: K. Pałecki (red.), Neutralization of Values in Law, Warszawa 2013, s. 223-224).

${ }^{32}$ Jest ona rozumiana jako „ogół zabiegów i ich następstw utrudniajacych lub uniemożliwiających ustanowienie funkcjonalnej zależności pomiędzy treścią regulująca jakichkolwiek decyzji prawnych a realnymi podstawami aksjologicznymi tych decyzji" (K. Pałecki, Neutralization of Values in Law - Main Concepts, w: idem (red.), op. cit., s. 58; M. Pękala, Neutralizacja aksjologiczna prawa, w: A. Kociołek-Pęksa, M. Stępień (red.), Leksykon socjologii prawa, Warszawa 2013, s. 153-154). W dyskusji nad tak rozumiana neutralizacją wartości w prawie M. Pękala (Lawmaking Principles and the Neutralization of Values in Law, w: K. Pałecki (red.), op. cit., s. 155) wprost podnosi, że neutralność/autonomia moralna prawa może sprzyjać „maskowaniu” określonych wartości faktycznie leżących u podstaw podejmowanych decyzji legislacyjnych, a więc wywoływać przytoczone zjawisko. Co warte podkreślenia, w debacie nad neutralnością/autonomią moralną prawa dostrzega się możliwość podobnej nietransparentności motywów 
Nieprzekładalność motywów na skutki należy także wiązać z zagadnieniem perspektywy, z której ocenia się prawo, podkreślanym powyżej przy okazji odwołania się do koncepcji indyferentności moralnej prawa ${ }^{33}$. Mianowicie, to co według legislatora jest neutralne, wcale takie nie musi być w ocenie adresatów konkretnych regulacji. Parafrazując znane angielskie przysłowie - moralność jest w „oczach obserwatora”. Zważywszy na to, należy zadać kolejne pytanie: Czyj punkt widzenia jest ważniejszy? Warunek neutralności proceduralnej jest tak naprawdę tylko formalny i może nie mieć żadnego wpływu na treść samego prawa. Społeczeństwo, do którego skierowane sa poszczególne normy prawne, oceniając je, raczej skupia się na najwyraźniej widocznym dla siebie elemencie, czyli treści, a nie na motywach wpływających na decyzje ustawodawcy, które moga być po prostu nieznane lub być przedmiotem manipulacji. Z pewnościa jednym z istotniejszych punktów odniesienia takiej oceny jest moralność opisowa znaczącej części adresatów.

Podstawą postulatu neutralności/autonomii moralnej prawa, będącego szczególną interpretacją liberalnego ideału ${ }^{34}$, jest chęć zapewnienia „równych szans” różnym koncepcjom życia ${ }^{35}$. Niewątpliwie jest to szczytna idea, ale jej realizacja jest niezwykle problematyczna. Przede wszystkim z punktu widzenia koncepcji, że każde prawo jest w pewnym stopniu ograniczeniem wolności, swobody działania ${ }^{36}$, może ona jawić się jako wewnętrznie sprzeczna. Mianowicie w dobie pluralizmu koncepcji dobrego życia poszczególne regulacje, nawet należące do tych gałęzi prawa, które zwykło się traktować jako neutralne, moga być przez poszczególnych adresatów oceniane jako wysoce opresyjne wobec nich $^{37}$. Jeśli takie ryzyko istnieje, to należy poszukiwać sposobów przeciwdziałaniu mu. Zdaje się, że najlepsze rozwiązanie sugeruje powszechny w polskiej myśli socjologicznoprawnej postulat, by tworzone prawo odpowiadało moralności znaczącej części adresatów - było z nią zgodne ${ }^{38}$. Kwestią dalszych ustaleń jest stopień tej zgodności.

tworzenia prawa (np. W. Sadurski, op. cit., s. 39; M. Błachut, op. cit., s. 41; T. Pietrzykowski, Z. Tobor, op. cit., s. 183; D. Bunikowski, op. cit., s. 134; W. Brzozowski, op. cit., s. 226 i 236 ; W. Ciszewski, op. cit., s. 13, przyp. 12), ale ryzyko jej wystapienia przy próbach zrealizowania tego postulatu nie traktuje się jako zarzut względem niego.

${ }^{33} \mathrm{~W}$ dyskusji nad neutralnością/autonomią moralną prawa problem perspektywy zauważaja, ale inaczej konceptualizują T. Pietrzykowski i Z. Tobor (op. cit., s. 185).

${ }_{34}$ Np. W. Sadurski, op. cit., s. 28.

35 Zob. także przegląd formułowanych uzasadnień tej koncepcji, np. M. Błachut, op. cit., s. 28 i n.; W. Ciszewski, op. cit., s. 10 i n.

${ }^{36}$ Np. J. Stelmach, op. cit., s. 95.

${ }_{37}$ Przykładem tego może być następująca sytuacja: dwie osoby zawierające między sobą umowę, której przedmiotem jest nieruchomość, nie dopełniają prawnego obowiązku dochowania formy aktu notarialnego, gdyż darzą się wzajemnie dużym zaufaniem i uważaja, że ingerencja „osób trzecich” jest niepotrzebna, a wręcz mogłaby być potraktowana jako oznaka podejrzliwości, a także nieuczciwości wobec kontrahenta. Strony żywiąc głębokie przekonanie o słuszności swojego wyboru moga potraktować prawne nieuznanie tak zawartej umowy jako wyraz opresji, dezaprobaty, oceny, iż ich postępowanie jest złe, niewłaściwe. Oczywiście współcześnie dokładnie ta sytuacja może nigdy nie być odzwierciedlona w rzeczywistości. Zdaje się jednak, że ten przykład może dawać wgląd w charakter ocen adresatów norm takich gałęzi prawa, które stosunkowo rzadko sa przedmiotem dyskusji i analiz dotyczących związków prawa i moralności.

${ }^{38} \mathrm{Na}$ gruncie prawa karnego zob. A. Krukowski, op. cit., s. 448. M. Borucka-Arctowa (Świadomość prawna a planowe zmiany społeczne, Wrocław-Warszawa-Kraków-Gdańsk-Łódź 1981, 
Przydatne uwagi dotyczące tego zagadnienia można odnaleźć w rozważaniach na temat wzajemnych relacji moralności i prawa karnego. Hasłu daleko idącego „umoralnienia” tej gałęzi prawa zarzuca się, że doprowadzi do terroru moralnego ${ }^{39}$. Taka obawa jest zasadna, jeśli to „umoralnienie” będzie polegało na odwzorowywaniu w regulacjach prawnokarnych określonych moralności normatywnych, postulowanych, czyli tych, które faktycznie nie funkcjonuja $\mathrm{w}$ społeczeństwie, a sa jedynie pewnymi projektami dobrego życia. Ponadto w omawianym zakresie pojawia się istotne zagadnienie, które można nazwać „archaizowaniem moralności przez prawo”. Mianowicie, wiele reform prawa karnego było motywowanych potrzebą usunięcia z niego elementów moralności $\mathrm{z}$ „ubiegłych stuleci” ${ }^{40}$. Jeśli w regulacjach prawnych odzwierciedlone sa niektóre normy moralne, to często prawo pełni wobec nich funkcję inercyjną. Dana norma, kiedyś należąca do sfery moralności deskryptywnej i prawnie „usankcjonowana”, wraz z rozwojem społeczeństwa przestała funkcjonować jako faktyczny regulator postępowania ludzi - norma uspołeczniona. Mogło to być spowodowane, przykładowo, jej nieprzystawaniem do aktualnych warunków czy dostrzeżeniem tego, że stosowanie się do niej było krzywdzące dla niektórych członków społeczeństwa. Treść tej normy następnie mogła stać się postulatem, przejść do określonej moralności normatywnej, podczas gdy odpowiadające jej prawo dalej obowiąuje, jest stosowane i przymusowo egzekwowane.

Wydaje się, że powyższa uwaga o możliwych przemianach, przejściach moralności z deskryptywnej do normatywnej ${ }^{41}$ pozwala na uściślenie wspomnianego socjologicznoprawnego postulatu, który w kontekście wielu możliwych ujęć moralności może wydawać się niejednoznaczny. Należy więc podkreślić, że najbardziej pożądany dla porządku społecznego wydaje się stan, w którym prawo w określonym stopniu odpowiada aktualnej moralności deskryptywnej, tej obserwowanej tu i teraz, rzeczywiście wpływającej na postępowanie ludzi, a nie pochodzącej z „epoki dyliżansów”42 bądź będącej czyimś wymysłem niezweryfikowanym w praktyce życia społecznego. Zatem odwzorowywanie $\mathrm{w}$ regulacjach prawnych już faktycznie funkcjonujących norm społecznych, do których należy moralność deskryptywna znaczącej części społeczeństwa, z dużą dozą prawdopodobieństwa będzie skutkować w uspołecznieniu samego prawa, zatem będzie narzędziem służącym realizacji tego ideału. Trzeba jednak podkreślić, iż $\mathrm{w}$ dobie wspomnianego pluralizmu moralności jest to problematyczne. W zasadzie wymagałoby to „uśrednienia”, „sprowadzenia do wspólnego mianownika" licznych koncepcji dobrego życia, które nieraz sa wobec siebie sprzeczne, lub wręcz antagonistyczne. Co więcej, prawne odzwierciedlanie moralności deskryptywnej, która może ulegać stosunkowo szybkim przemianom, stanowiłoby poważne zagrożenie dla stabilności, pewności prawa.

\footnotetext{
s. 135) pisze o tym jako o ogólnej dyrektywie niezwiązanej z konkretną gałęzią prawa. Zob. także K. Pałecki, Prawoznawstwo..., s. 107.

${ }^{39}$ A. Wasek, W kwestii tzw. odmoralizowania prawa karnego, „Studia Filozoficzne” 1985, nr 2-3, s. 241.

${ }^{40}$ Idem, Prawo karne..., s. 46.

${ }^{41}$ Możliwy jest także przeciwny „kierunek” takiej przemiany: z moralności normatywnej do deskryptywnej.

${ }^{42}$ A. Wassek, W kwestii tzw. odmoralizowania..., s. 225.
} 


\section{PODSUMOWANIE - NEUTRALNOŚĆ/AUTONOMIA MORALNA PRAWA A USPOLECZNIENIE PRAWA}

W świetle powyższych uwag koncepcja neutralności/autonomii moralnej prawa jawi się jako wysoce problematyczna, i to z innych względów niż często podnoszone w literaturze i nierzadko nietrafione wątpliwości względem niej ${ }^{43}$. Przede wszystkim można jej zarzucić fasadowość. Ze względu na kontrowersyjne zagadnienie możliwości faktycznego wystrzegania się określonych motywów, przekonań w podejmowaniu decyzji prawodawczych, próby realizacji takiego postulatu można by oceniać jako manipulacje. Jeśli do tego ma prowadzić koncepcja wprost odwołująca się do moralności, to jej wiarygodność staje pod dużym znakiem zapytania. Ponadto skupianie się na perspektywie ustawodawcy jest po prostu niezrozumiałe, nie tylko w świetle zagadnienia uspołeczniania prawa, ale już z powodu samej zasadniczej ratio komentowanej koncepcji. Ma ona być przecież swoistego rodzaju odpowiedzią na obserwowany pluralizm koncepcji dobrego życia wśród adresatów prawa. Jeśli wychodzi się od takiej niewątpliwie słusznej obserwacji, to dlaczego przekonuje się, że właściwym podejściem do takich realiów będzie de facto przesunięcie akcentów w motywach i uzasadnieniach tworzonego prawa, które może nie mieć żadnego wpływu na jego treść i odbiór w społeczeństwie?

Ten „ustawodawcocentryzm” jest również niezrozumiały z punktu widzenia wspomnianych dokonań socjologii prawa. Podejmując próby realizacji ideału możliwie najszerszego uspołecznienia prawa, prawodawca musi liczyć się z koniecznością odzwierciedlania tego, co aktualnie funkcjonuje w społeczeństwie. Z perspektywy adresatów takie prawo raczej nie będzie oceniane jako wyraz arbitralnych preferencji legislatora, tylko jako stwierdzenie oczywistości, któremu nie towarzyszy poczucie ograniczenia własnej wolności. Należy jednak podkreślić, że odwzorowywanie nie może być bezrefleksyjne. Chyba największą trudnością z tym związaną jest konieczność dokładnego odróżniania aktualnej moralności deskryptywnej znaczącej części adresatów prawa od partykularnych, ale często bardzo „roszczeniowych” i widocznych w dyskursie publicznym moralności normatywnych. Jak już ponad 100 lat temu wskazywał Juliusz Makarewicz, dokładne wsłuchiwanie się w „głos ludu” skutkowałoby tym, że współcześnie wciąż odbywałyby się procesy czarownic ${ }^{44}$. By uniknąć podobnych konsekwencji, ustawodawca musi wykazywać się daleko idącą ostrożnościa, a nawet odwaga, by odmówić prawnego „usankcjonowania” poszczególnych elementów danej moralności postulowanej (a niekiedy i faktycznie przeżywanej) przez część społeczeństwa, część wyborców ${ }^{45}$.

${ }^{43}$ Nie powtarza się tu bowiem np. zarzutu nieneutralności samego postulatu neutralności/autonomii moralnej prawa (liberalny rodowód tej koncepcji jest powszechnie znany i ujawniany), czy zarzutu niemożliwości wyrugowania wartości z procesu podejmowania decyzji prawodawczych (w komentowanym postulacie nie chodzi o oczyszczenie działalności legislacyjnej z jakichkolwiek wartości, tylko o wykluczenie z niej pewnej klasy racji, motywów). Por. popularne krytyki neutralności/autonomii moralnej prawa, np. M. Błachut, op. cit., s. 156 i n.

44 Za: L. Gardocki, Zagadnienia teorii kryminalizacji, Warszawa 1990, s. 76.

45 Nie jest to jedyny problem związany z sugerowanym tu „przechyleniem szali” z neutralności/autonomii moralnej prawa na stronę idei uspołeczniania prawa. Jej urzeczywistnienie bar- 
Mimo całego szeregu praktycznych problemów związanych z zadaniem uzgadniania prawa z aktualną i faktyczną moralnościa, dążąc do jak najszerszego uspołecznienia prawa, ten postulat zdaje się bardziej zasadny niż budząca wiele wątpliwości koncepcja neutralności/autonomii moralnej prawa. Próby jej realizacji moga bowiem doprowadzić do wykształcenia się nieoficjalnych norm dotyczacych tworzenia i uzasadniania prawa, niekoniecznie zasługujacych na aprobatę. Oczywiście to odwzorowywanie również może być okazją do manipulacji, jak chyba każdy warunek stawiany prawodawcy. Należy jednak odróżniać postulaty „tylko” potencjalnie stwarzające sposobność manipulacji od tych, które z dużą dozą prawdopodobieństwa do niej doprowadzą. W końcu, punktem odniesienia weryfikacji procesu uzgadniania prawa z moralnościa deskryptywna jest intersubiektywnie obserwowalna i z powodzeniem zdatna do empirycznego zbadania sfera praktyki społecznej. Ewentualne manipulacje sa więc trudniejsze do przeprowadzenia, gdyż można je stwierdzić i udowodnić fałsz podmiotom, które chcą się ich dopuścić. Natomiast zupełnie innego rodzaju jest punkt odniesienia stwierdzenia realizacji lub złamania standardu neutralności/autonomii moralnej prawa. Chodzi w nim bowiem o z ogromnymi trudnościami weryfikowalne, jeśli nie całkowicie niemożliwe do sprawdzenia, motywacje kryjące się za danymi decyzjami prawodawcy ${ }^{46}$.

dr Michat Dudek

Uniwersytet Jagielloński

michal.dudek@uj.edu.pl

dzo często zależne jest od odzwierciedlania w regulacjach prawnych moralności deskryptywnej znaczącej części adresatów prawa. W takich przypadkach siłą rzeczy dochodzi do faworyzowania jednej koncepcji życia nad pozostałe, a na takie rozwiązanie wiele osób o zapatrywaniach liberalnych (pamiętając jednak o „nieostrości” liberalizmu i jego wielu odmianach) raczej nie mogłoby wyrazić zgody.

${ }^{46}$ W. Sadurski (op. cit., s. 38-39; zob. także W. Brzozowski, op. cit., s. 96-104) podnosi ten problem i uważa, że test na stwierdzenie zrealizowania bądź złamania neutralności/autonomii moralnej prawa należy przeprowadzać przez rozumowanie ze środków na cele. To rozwiąanie nie wydaje się przekonujące. Przede wszystkim, wbrew jego założeniom, próby przeprowadzenia takiego testu najpewniej nie obyłyby się jednak bez brania pod uwagę sfery motywów ustawodawcy, choćby tylko tych uzewnętrznianych w formie uzasadnień aktów normatywnych, a przecież te w założeniu powinny być zgodne z rzeczywistymi przesłankami decyzji legislacyjnych. Samo przeprowadzenie tego testu zdaje się więc konsekwencją założenia, że motywy danej inicjatywy ustawodawczej komunikowane przez jej autorów sa fałszywe, a to jest niczym innym jak swoista formą twierdzenia o faktycznych, subiektywnych przesłankach decyzji, do których przypominany test ma się w ogóle nie odnosić. Ponadto test ten jest wątpliwy z uwagi na bardzo duże ryzyko subiektywizmu w rozumowaniu przeprowadzajaccych test - projektowaniu przez nich swoich indywidualnych i niekoniecznie obiektywnie poprawnych zapatrywań na to, jakie środki są właściwe do osiagnięcia konkretnych celów (por. M. Błachut, op. cit., s. 95-96). Kryterium obiektywizującym i uprawomocniającym wyniki takiego rozumowania mogłyby być wnioski z badań socjologicznoprawnych przedstawiajace, co i za pomoca jakich regulacji najsprawniej osiagnąć. Tymczasem przypominana koncepcja testu w jego komentowanym tu sformułowaniu bardzo zdawkowo sugeruje potrzebę oparcia jego praktycznego przeprowadzenia na wynikach wnikliwych badań empirycznych (W. Sadurski, op. cit., s. 39). 


\section{AUTONOMY, NEUTRALITY, AND MORAL INDIFFERENCE OF LAW IN THE CONTEXT OF SOCIALISED LAW}

\section{Summary}

According to the concept of moral neutrality/autonomy of law, law-making motivated by the belief that some ways of life are better than others is not allowable. This concept also establishes a need for such justification of the proposed law that it could not be considered as an indication of preferences of one morality over another. The article is an attempt to look at the moral neutrality/autonomy of law from a socio-legal perspective, emphasising the ideal of socialised law, that is the law that is actually and voluntarily (without the need for 'external' coercive enforcement) observed by its addressees. The concept of moral indifference of law (a situation in which law regulates the behaviour that is not simultaneously regulated by morality) is helpful in this argumentation. The article shows that the moral neutrality/autonomy of law is highly problematic; for example it is not focused on the question to whose and which morality should the legislator be neutral, or whether it is even possible for the legislator to have this characteristic of objectivity. An emphasis is placed on the problem that neutral motives do not always result in neutral law. This justifies the opinion that moral neutrality/autonomy of law seems to merely create the impression of a solution to a problem, while it actually generates more problems. Attempts to put this concept into practice can in fact lead to manipulation in the legislative process and formation of questionable, unofficial norms of law-making and justification of law. Assuming that any law can be seen by its addressees as oppressive, the best way to counteract such negative opinions of the law (and their possible negative consequences) is the pursuit for a socialised law. However, the realisation of this idea also faces a number of difficulties. 
Copyright of Journal of Law, Economics and Sociology is the property of Faculty of Law and Administration of Adam Mickiewicz University in Poznan and its content may not be copied or emailed to multiple sites or posted to a listserv without the copyright holder's express written permission. However, users may print, download, or email articles for individual use.

Właścicielem praw autorskich do „Ruchu Prawniczego, Ekonomicznego i Socjologicznego” jest Wydział Prawa i Administracji Uniwersytetu im. Adama Mickiewicza w Poznaniu. Zawartość czasopisma nie może być kopiowana, przesyłana do innych stron internetowych bądź zamieszczana na blogach bez pisemnej zgody wydawcy. Niemniej artykuły można drukować, kopiować lub przesyłać w formie elektronicznej na własny użytek. 